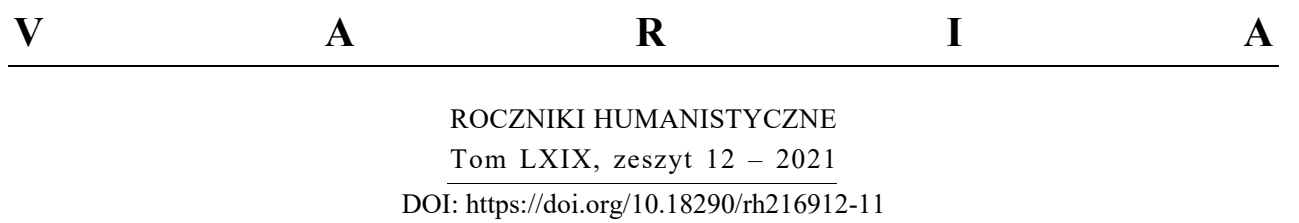

JACEK BRAMORSKI

\title{
TEOLOGICZNE ASPEKTY MUZYKI W UJĘCIU FLAWIUSZA AURELIUSZA KASJODORA
}

Kasjodor to wybitny wczesnochrześcijański myśliciel, pisarz i organizator monastycznego życia naukowego. Charakteryzując go, Władysław Tatarkiewicz trafnie zauważał, że chociaż żył ,już po upadku starożytnego świata, ale posiadał jeszcze autentyczną wiedzę starożytnych" (Historia estetyki 94). Dynamizm wszechstronnej działalności Kasjodora czynią z niego ważnego świadka przełomu dziejowego - upadku Cesarstwa Rzymskiego na Zachodzie oraz początku nowej rzeczywistości społeczno-politycznej i kulturowej.

Jego życiowa postawa oraz dzieła wyrażają niezwykle aktualną ideę spotkania kultur, dialogu i pojednania. Żyjąc w jednym z najbardziej niespokojnych okresów w historii chrześcijańskiego Zachodu, Kasjodor pragnął dokonać syntezy tradycji rzymsko-chrześcijańskiej i nowej kultury przyniesionej przez wojownicze plemiona Gotów. Jednak ówczesne uwarunkowania polityczne nie pozwoliły mu na zrealizowanie tego ambitnego planu. W obliczu zmierzchu kultury antycznej oraz zamętu swojej epoki, Kasjodor podjął się zadania polegającego na zachowaniu oraz przekazaniu potomnym dziedzictwa myśli starożytnej. Dotyczyło to również antycznej teorii muzyki, którą interpretował w duchu chrześcijańskim. Uznać go zatem można za jednego z prekursorów teologicznej refleksji nad muzyką, którą rozpatrywał w świetle Pisma świętego i moralności ewangelicznej. Będąc człowiekiem głęboko religijnym uważał, że z pomocą łaski Bożej najwięcej można wydobyć z objawionego Słowa, posłu-

Ks. dr hab. JACEK BRAMORSKI, prof. AM - Katedra Muzyki Kościelnej Akademii Muzycznej im. Stanisława Moniuszki w Gdańsku; adres do korespondencji: ul. Łąkowa 1-2, 80-743 Gdańsk; e-mail: j.bramorski@amuz.gda.pl; ORCID: https://orcid.org/0000-0002-5742-9428.

Rev. Dr. Hab. JaCeK Bramorski, Associate Professor at the Stanisław Moniuszko Academy of Music in Gdańsk, Department of Church Music; address for correspondence: ul. Łąkowa 1-2, 80-743 Gdańsk, Poland; e-mail: j.bramorski@amuz.gda.pl; ORCID: https://orcid.org/0000-0002-5742-9428. 
gując się zdobyczami naukowymi i artystycznymi, jakie przekazali starożytni Grecy i Rzymianie (por. Benedykt XVI 47). W styczniu 2020 roku w Squillace (Kalabria, Włochy) rozpoczął się na poziomie diecezjalnym proces beatyfikacyjny i kanonizacyjny tego niezwykłego świadka wiary i uczonego. Doceniając jego wielkie zasługi dla Kościoła i kultury europejskiej, Feliks Koneczny podkreślał, że cywilizacja łacińska zawdzięcza swoje ideowe oblicze Kasjodorowi, którego z tego względu nazwał ,jednym z największych ludzi w całej historii powszechnej" (Obronić cywilizację tacińska 168).

\section{W SŁUŻBIE SPOTKANIA KULTUR, DIALOGU I POJEDNANIA}

Flawiusz Aureliusz Kasjodor Senator urodził się ok. 485 r. w Scyllacium (obecnie Squillace) jako potomek arystokratycznej rodziny pochodzenia syryjskiego. Wszechstronne wykształcenie klasyczne otrzymał prawdopodobnie w Rzymie. W jego życiu i działalności można wyróżnić dwa okresy. Pierwszy związany był z jego służbą publiczną w Italii podczas panowania królów ostrogockich (zwłaszcza Teodoryka Wielkiego). Drugi okres (od ok. 550 r.) wypełniony był aktywnością w dziedzinie nauki i wychowania w założonym przez Kasjodora klasztorze Vivarium.

Dzięki wybitnym zdolnościom intelektualnym i organizacyjnym Kasjodor zrobił na dworze królów ostrogockich błyskotliwą karierę urzędniczą, pełniąc kolejno funkcje doradcy prefekta, skarbnika pałacu królewskiego, konsula, kanclerza oraz praefectus praetorio, czyli jednej z najbardziej wpływowych osób w państwie. Zachowane pisma, które redagował Kasjodor jako kanclerz, nie tylko mają wielką wartość historyczną, ale także stanowią świadectwo jego pisarskiego kunsztu. W późniejszym okresie stały się one wzorem dla wielu kancelarii urzędowych. Pełniąc zaszczytne i odpowiedzialne funkcje polityczne, Kasjodor nie zapominał o potrzebie kształcenia młodego pokolenia. Italia doświadczała wówczas głębokiego regresu kultury. Brakowało szkół wyższych, a wiele bibliotek uległo zniszczeniu na skutek wojen i wędrówek ludów. Dlatego Kasjodor zabiegał o rozwój wyższego szkolnictwa kościelnego na Zachodzie, dostrzegając potrzebę budowania naukowych podstaw dla życia religijnego. W tym celu, wraz z papieżem św. Agapitem I (535-36) podjął próbę założenia w Rzymie, w rodzinnej posiadłości papieża na wzgórzu celiańskim, wyższej uczelni teologicznej wraz z biblioteką, na wzór dawnej szkoły w Aleksandrii oraz w Nisibis. Niestety, śmierć papieża oraz wojny gocko-bizantyjskie nie pozwoliły mu zrealizować tego zamierzenia (por. Bower 244; Lohr 372-74). 
Kasjodor jako patrycjusz i królewski doradca, w swojej służbie państwowej współpracował z Rzymianami, którzy wspierali w Italii polityczne wpływy Gotów. Nie było to jednak wynikiem koniunkturalizmu, ale raczej dążenia do tego, aby przez dialog budować nową, chrześcijańską przyszłość ówczesnej Europy. Wraz z Boecjuszem i Symmachem pracował nad zbliżeniem polityczno-kulturalnym pomiędzy Rzymianami a Gotami oraz przyczynił się do utrzymania pokoju z cesarstwem wschodnim. Świadczy o tym m.in. jego dzieło Chronica minora, w której zawarł ideę pojednania Rzymian z Gotami (por. Longosz, Kasjodor 529-34; Zwolski 65-88).

Po zdobyciu w 540 roku Rawenny przez Belizariusza, Kasjodor przebywał w Konstantynopolu i przyjął postawę lojalną wobec cesarza Justyniana. Gdy powrócił do Italii, wycofał się z życia publicznego i poświęcił się pracy naukowej. Ten kluczowy moment w życiu Kasjodora można określić mianem „nawrócenia”. We wstępie do Expositio in Psalterium, pisze: „Porzuciwszy wreszcie w stolicy raweńskiej zabiegi o godności i świeckie troski, zaprawione smakiem szkody, gdy poczułem językiem duszy miody psałterza niebieskiego, jak człowiek, który łaknie, zatopiłem się chciwie w badaniach, by słodko spijać słowa zbawcze po gorzkich czynach" (PL 70, 10). Patrycjusz stał się zatem mnichem i przeniósł się do rodzinnej posiadłości w Kalabrii, podejmując tam działalność naukowo-dydaktyczną oraz organizacyjną. Około 554 roku założył w Scyllacium Vivarium - swoiste połączenie klasztoru i ośrodka naukowego, w którym intelektualny wysiłek mnichów traktowany był jako wartość niezbędna. Pracował tam aż do swej śmierci w 580 roku (por. Williams i Balensuela 38-39; Bower 244).

Vivarium był swoistą ,arką”, dzięki której Kasjodor pragnął ocalić dziedzictwo kultury starożytnej z ,potopu” wojen i zamętu. W tym celu, oprócz podstawowych ślubów zakonnych, mnisi podejmowali zobowiązanie do prowadzenia pracy naukowej nie tylko w zakresie gruntownej znajomości Biblii i traktatów teologicznych, ale także w szerokim wymiarze ogólnokulturowym. Wspaniale usytuowany na wzniesieniu $\mathrm{z}$ widokiem na morze, otoczony ogrodami i winnicami kompleks klasztorny obejmował osobne miejsce dla eremitów (anachoretów) zwane mons Castellus oraz część dla mnichów żyjących we wspólnocie (cenobitów), będące właściwym Vivarium (nazwa ta prawdopodobnie pochodzi od znajdujących się tam stawów rybnych - vivaria). Uczony Kalabryjczyk pragnął, aby wzorem starożytnych szkół greckich miejsce to jako chrześcijański locus amoenus sprzyjało kontemplacji i poprzez piękno rzeczywistości ziemskiej pozwalało doświadczać wspaniałości rzeczywistości niebiańskiej (por. Bäbler 107-13; Kieling, Rola Pisma 40-42; Lohr, Kasjodora 
klasztor Vivarium 375-78). Najnowsze badania archeologiczne prowadzone w Squillace rzuciły światło na wiele nieznanych wcześniej szczegółów dotyczących życia w Vivarium (Pagano).

Znajdujący się w klasztorze ośrodek naukowy składał się z czterech części: biblioteki, skryptorium, korektorium oraz miejsca, w którym opracowywano tłumaczenia. W uznawanej za największą wówczas w Italii bibliotece zgromadzono nie tylko grecko-łacińskie kodeksy i komentarze biblijne, ale również dzieła Ojców Kościoła oraz greckie i łacińskie pisma myślicieli antycznych. Biblioteka Vivarium była skarbnica wiedzy nie tylko z dziedziny Pisma Świętego i teologii, ale także w zakresie siedmiu sztuk wyzwolonych (septem artes liberales), czyli gramatyki, retoryki i dialektyki (trivium) oraz arytmetyki, geometrii, astronomii oraz muzyki (quadrivium). W skryptorium zakonnicy przepisywali księgi, a następnie sprzedawali je, co było początkiem swego rodzaju działalności wydawniczej. Ich dziełem był m.in. Codex Grandior (uznany obecnie za zaginiony), będący jednym z pierwszych, jednotomowych łacińskich egzemplarzy Pisma Świętego. Posłużył on za podstawę do opracowania słynnego Codex Ammiatinus (por. Marsden 118-28). Kolejnym ważnym ogniwem ośrodka monastyczno-naukowego Vivarium było korektorium, w którym mnisi, zgodnie z zasadami ortograficznymi, poprawiali kodeksy, zwłaszcza komentarze biblijne. W obliczu coraz szybciej zanikającej na Zachodzie znajomości języka greckiego, niezbędnym elementem pracy naukowej było tłumaczenie ksiąg greckich na łacinę, które odbywało się w tzw. translatorium. Pracowano tam zarówno nad przekładami komentarzy biblijnych, jak i pism historycznych, medycznych i filozoficznych, w tym także dotyczących muzyki (por. Kieling, Rola Pisma 51-54; Longosz, Kasjodor 531).

Ideą, która przyświecała Kasjodorowi było nie tylko zachowanie, ale także przybliżenie zmieniającej się kulturowo Europie dziedzictwa starożytności odczytywanego w duchu chrześcijańskim (por. Gondek 128-32). Można zatem nazwać uczonego Kalabryjczyka prekursorem inkulturacji, ponieważ zachowując ortodoksję, podejmował ewangelizacyjny dialog nie tylko z myślą antyczną, ale także z nowymi ludami europejskimi. Św. Jan Paweł II w encyklice Fides et ratio, stwierdził, że gdyby Kościół w zetknięciu z wielkimi kulturami starożytnej Grecji i Rzymu odrzucił „to dziedzictwo sprzeciwiłby się opatrznościowemu zamysłowi Boga" (72).

Vivarium było także miejscem studiów, których szczegółowy program opracował Kasjodor, zwracając uwagę nie tylko na dogłębną znajomość Biblii, ale także tzw. sztuk wyzwolonych (por. Kieling, Rola Pisma 105-66). Pomocą w realizacji tego zamierzenia były opracowane przez niego Institutiones divi- 
narum et humanarum litterarum (,Zasady nauk boskich i ludzkich”). Dzieło to składało się z dwóch części - pierwsza poświęcona była wprowadzeniu do teologii, druga natomiast stanowiła swoisty podręcznik dyscyplin wchodzących w skład trivium i quadrivium. Zgodnie z tradycją myśli pitagorejskiej, w quadrivium umieszczono obok matematyki traktat Institutiones musicae (,Zasady muzyki”). Institutiones nie zawierały obszernych analiz, ale były zwięzłym podręcznikiem, mającym na celu przygotowanie mnichów do dalszej pracy naukowej. Zwięzłość przedstawienia najważniejszych zagadnień dotyczących nauk teologicznych i świeckich zdecydowała o tym, że w późniejszych wiekach opracowane przez Kasjodora kompendium stało się bardzo popularne i wywarło znaczący wpływ na ukształtowanie stylu edukacji w szkolnictwie kościelnym średniowiecznej Europy. Chociaż po śmierci swego założyciela klasztor Vivarium nie przetrwał, to jednak stał się wzorem do naśladowania w uczelniach następnych wieków (por. Gondek 127-28). Kasjodor pracował dla potomności, zgodnie z wezwaniem Psalmisty: „Należy to spisać dla pokolenia, co przyjdzie" (scribantur haec in generatione altera) (Ps 102, 19). Panujący w jego czasach zamęt nie pozwolił zaowocować dalekowzrocznym inicjatywom, ale bez wątpienia dzięki dziełu, jakim było Vivarium mogła narodzić się średniowieczna christianitas (por. Daniélou i Marrou, 324-25).

\section{CHRZEŚCIJAŃSKA RECEPCJA ANTYCZNEJ TEORII MUZYKI}

Założyciel klasztoru w Vivarium kontynuował najważniejsze wątki antycznej teorii muzyki podjęte przez św. Augustyna i Boecjusza. Należy do tych myślicieli, którzy „przechowali i przekazali średniowieczu grecką wiedzę o muzyce” (Tatarkiewicz 139), odczytując ją w perspektywie chrześcijańskiej. Kasjodor, analizując dzieła autorów pogańskich oraz czerpiąc z Biblii i pism Ojców Kościoła, dokonał bardzo ciekawej syntezy poglądów odnoszących się do zagadnień muzycznych. Jak zauważa Frederick Copleston, nie dążył on „do nowatorstwa czy oryginalności myśli, lecz do sporządzenia streszczenia nauk, które zebrał od innych autorów" (Historia filozofii 98). Sam Kasjodor skromnie przyznawał, że w dziedzinie muzyki nie przekazuje własnych poglądów, ale naukę przekazaną przez wcześniejszych myślicieli: „Teraz powiedzmy o częściach muzyki, jak zostało przekazane przez poprzedników (sicut est a maioribus traditum, prosequamur)" (Zasady muzyki 18-19). Jednak dogłębna refleksja nad przedstawioną $\mathrm{w}$ jego pismach koncepcją muzyki pozwala dostrzec $\mathrm{w}$ niej elementy świadczące o twórczym rozwinięciu idei odziedziczonych po przodkach. 
W nakreślonej przez Kasjodora w Institutiones divinarum et humanarum litterarum integralnej wizji nauczania nie mogło zabraknąć refleksji nad muzyką, której poświęcona jest piąta księga tego dzieła zatytułowana Institutiones musicae. 2.V. De musica. Już w pierwszych rozdziałach Institutiones musicae Kasjodor nawiązuje wyraźnie do tradycji pitagorejskiej, stwierdzając: „Pitagoras zaświadcza, że ten świat może być stworzony i kierowany przez muzykę" (Zasady muzyki 17). Założyciel Vivarium interpretuje jednak to antyczne przekonanie w perspektywie teologicznej. Według niego, muzyka ma charakter uniwersalny, gdyż „także niebo i ziemia i wszystko, co na nich boskim rozporządzeniem się dzieje, nie istnieje bez muzyki” (Zasady muzyki 17). Zastosowanie w tym miejscu przez Kasjodora określenie „niebo i ziemia” (caelum et terra) przywodzi na myśl biblijny hymn o stworzeniu świata, który rozpoczyna Pismo Święte: „Na początku Bóg stworzył niebo i ziemię” (Rdz 1, 1). Medytując nad popularną w starożytności koncepcją harmonii sfer, Kasjodor pojmował ją w duchu chrześcijańskim, odwołując się do dzieła stworzenia świata przez Boga. Stwórca mógł zatem już od samych początków napełniać i kierować universum poprzez muzykę. Takie ujęcie pitagorejskiej koncepcji harmonii sfer świadczy o dążeniu Kasjodora do pogodzenia najcenniejszych idei świata antycznego z wiarą chrześcijańską. Jednocześnie odwołuje się on do wymiaru moralnego, dodając: „Muzyka z tego powodu rozpościera się na wszystkie czynności naszego życia; zwłaszcza jeśli wypełniamy przykazania Stwórcy i czystymi umysłami zachowujemy ustalone przez niego zasady" ( $\mathrm{Za}$ sady muzyki 17).

Znamienne jest to, że Kasjodor na początku swoich rozważań o muzyce $\mathrm{w}$ Instututiones musicae ukazuje ją w perspektywie relacji człowieka do Stwórcy i do ustanowionych przez Niego przykazań (por. Bower 244). Wskazuje to wyraźnie na umieszczenie muzyki w obszarze teologii moralnej. Ponadto Kasjodor wyraża przekonanie, że każda sfera życia człowieka poddana jest prawidłom muzycznym, zarówno w aspekcie duchowo-etycznym, jak i cielesnym. Muzyka nie tylko kształtuje sposób wyrażania się człowieka na zewnątrz, ale przenika również jego wnętrze: „Cokolwiek mówimy albo jesteśmy poruszani wewnątrz pulsowaniem tętnic, jest związane z mocą harmonii przez muzyczne rytmy" (Zasady muzyki 17). Wybitny polski kardiolog, a jednocześnie znawca kultury antycznej, Andrzej Szczeklik zwraca uwagę na medyczne uzasadnienie starożytnej intuicji o muzycznym rytmie obecnym w organizmie ludzkim, począwszy od poziomu komórkowego, poprzez procesy zachodzące w mózgu aż do pracy serca i układu krążenia. Jeśli definiujemy „rytm jako oblicze muzyki, zwrócone w stronę czasu”, to „nasze wielkie 
narządy wewnętrzne i komórki, które je tworzą, (...) czują, słyszą szum i rytm krwi, która (...) mówi im o przepływie czasu" (Katharsis 76).

Kasjodor pojmował muzykę jako relację pomiędzy dźwiękami oraz jako harmonię i rytm wewnętrzny w człowieku. Komentując w Expositio psalmorum Psalm 97, Kasjodor definiował, że „muzyka jest sztuką, która analizuje harmonizujące ze sobą przedmioty (rerum sibi congruentium), to jest różnice i zgodności tonów" (PL 70, 692). Takie określenie muzyki pozwoliło mu ukazać ją jako odzwierciedlenie relacji pomiędzy Bogiem a człowiekiem. Podporządkowanie się woli Stwórcy jest wyrazem wewnętrznej harmonii i etycznej równowagi ludzkiego życia (por. Kieling, Ars musica 47-48). Bóg i Jego prawo moralne są podstawowym punktem odniesienia dla harmonii osoby ludzkiej. Ponadto Kasjodor zwracał uwagę, że „psalmy częstokroć bywają odgrywane na instrumentach muzycznych, które nie tyle cieszą zmysł słuchu, co pobudzają serca słuchaczy (provocare potius cordis auditum)" (PL 70, 692). Dzięki temu muzyka staje się pomocą w poznawaniu zawartych w przykazaniach tajemnic Bożej woli. Dobrze wykonana melodia nie tylko symbolizuje duchową harmonię w człowieku, ale wskazuje na harmonię najdoskonalszą, której źródłem jest sam Bóg (por. Kieling, Rola Pisma 192-93; Tatarkiewicz 100).

Jest to oryginalna reinterpretacja koncepcji musica humana sformułowanej przez Boecjusza. Dla Kasjodora harmonia muzyczna nie wyraża jedynie współdziałania duszy i ciała, ale wpisuje się w wielką symfonię, ,której partyturą jest prawo Boże, a instrumentem czysty umysł (wolne od grzechu serce)" (Dyka 37). Piękno muzyki, będącej symbolem harmonii duchowej, nie tylko oddziałuje na człowieka, ale także stanowi wyraz jego moralnej doskonałości. Za przejaw najwyższej harmonii słów i czynów uznawał on posłuszeństwo Bożym przykazaniom. W ten sposób muzyka odzwierciedla powinność, aby człowiek niejako „dostroił się do Boga” (Lohr, Zagadnienia muzyki 310). Ponadto wskazuje na harmonię jeszcze doskonalszą, ukierunkowując duszę ku Bogu i dając jej przedsmak wiecznego szczęścia (por. Fubini 84; James 79; Tatarkiewicz 95).

Definiując muzykę w Institutiones musicae, Kasjodor nawiązał do znanego w starożytności określenia autorstwa rzymskiego gramatyka Censorymusa, stwierdzając: „Muzyka oczywiście jest umiejętnością pięknego śpiewania” (scientia bene modulandi) (Zasady muzyki 16-17). Do tej definicji odwołał się w traktacie De musica św. Augustyn i bardzo często to on uznawany jest błędnie za jej autora (Dyka 39; Longosz, Patrystyczne traktaty 192). Kasjodor rozwinął ją w perspektywie teologiczno-moralnej, dodając: „Dlatego jeśli kierujemy się dobrym obyczajem, uznajemy się za stale zjednoczonych z tak wspaniałą umiejętnością. Kiedy jednak popełniamy czyny niegodziwe, nie mamy 
w sobie muzyki" (Zasady muzyki 17). Ponownie Kasjodor odwołuje się do teologiczno-moralnego wymiaru muzyki, która ściśle związana jest z „dobrym obyczajem" (bona conversatione), który pozwala człowiekowi zespolić się z muzyką w sensie duchowym. Ład etyczny jest zatem warunkiem osiągnięcia harmonii ludzkiego życia na wzór doskonałej harmonii muzycznej. Można w tym odnaleźć dalekie nawiązanie do koncepcji Platona, dla którego mędrzec to mousikós anèr w sensie duchowo-etycznym (por. Lohr, Zagadnienia muzyczne 311). Raz jeszcze Kasjodor powraca do tej myśli w trzecim rozdziale Institutiones, wskazując w symboliczny sposób nie tylko na religijno-liturgiczny, ale również etyczny wymiar muzyki: „Również [muzyka] wiąże się z religią w różny sposób, tak że istnieją: dekachord Dekalogu..." (Zasady mu$z y k i$ 19). Zastosowana w tym miejscu przez Kasjodora oryginalna metafora „dekachord Dekalogu” (Decalogi decacordus) ma charakter poetycki i jest nawiązaniem do Dziesięciu Przykazań, przekazanych Mojżeszowi przez Boga na Górze Synaj (por. Wj 20, 1-21). Charakterystyczną i oryginalną cechą kasjodorowskiej koncepcji muzyki jest podkreślenie jej sensu teologiczno-moralnego, uwarunkowanego wewnętrzną harmonią człowieka, którego czyny zgodne są z Bożym Prawem.

Kasjodor łączy również w swojej teorii muzyki perspektywę teologiczną z wymiarem estetyczno-artystycznym, stwierdzając: „Niezwykle przyjemna i bardzo pożyteczna jest znajomość [muzyki], która zarówno nasz umysł podnosi ku sprawom boskim, jak też uszy pieści piękną melodią" (sensum nostrum ad superna erigit et aures suavi modulatione permulcet) (Zasady muzyki 24-25). Zwracał uwagę, że studiowanie muzyki jest najbardziej pożyteczne, gdyż wznosi ludzki umysł ku transcendencji, a także poprzez piękno melodii sprawia człowiekowi godziwą przyjemność. Taka ocena ugruntowała pozycję muzyki pośród innych sztuk jako najbardziej „uduchowionej” (por. Tatarkiewicz 101).

Kasjodor w swej refleksji nad muzyką kładł nacisk na jej wymiar religijnowychowawczy. W Epistola ad Boetium podkreślał, że muzyka nie tylko „uszy koi melodią” (aures modulatione permulcet), ale także „kieruje umysł nasz ku wyższym rzeczom” (sensum nostrum ad superna erigit). Ponadto „dzięki muzyce trafnie myślimy [competenter cogitamus], pięknie mówimy [pulchre loquimur] i odpowiednio się poruszamy [convenienter movemur]" (PL 69, 571). Nawiązując do antycznej teorii etosu muzycznego, Kasjodor zwracał uwagę na „oczyszczający” charakter muzyki. Dając świadectwo Bożej prawdy, budzi ona pięknem dźwięków uśpione dusze, uwalnia od namiętności, umacnia dobre uczucia, a przez to poucza, wzrusza i pociesza (por. Morawski 40). 


\section{BIBLIJNE MOTYWY W KONCEPCJI MUZYKI}

W swojej refleksji nad muzyką Kasjodor sięgał nie tylko do myśli filozofów starożytnych, ale również do tradycji biblijnej. Według niego wszelka wiedza ma jedno „praźródło” - Biblię. W Piśmie Świętym zawarte są jakby „nasiona” różnych dyscyplin naukowych - siedmiu artes liberales, a wśród nich także muzyki. Znajomość poszczególnych artes otwiera drogę do Mądrości Bożej. Sztuki wyzwolone nie stoją bowiem w opozycji do Słowa Bożego, ale wraz z teologią są nieodzowną częścią integralnie pojętej nauki chrześcijańskiej (por. Kieling, Ars musica 47; Gondek 132).

W rozdziale trzecim Instititiones musicae Kasjodor opisuje znane w Piśmie Świętym instrumenty muzyczne, wyjaśniając ich teologiczną symbolikę. Przykładem tego jest wspomniane już wcześniej metaforyczne określenie „dekachord Dekalogu", które nie tylko wskazuje na moralny sens muzyki, ale jest również odwołaniem do jej biblijnych źródeł. Dekachord (psalterium) wymieniany jest m.in. w Księdze Psalmów jako instrument o dziesięciu strunach lub o dziesięciu dźwiękach (por. Ps 32, 3; Ps 143, 9). Także inne instrumenty, o których wspomina Kasjodor mają biblijną proweniencję, np. cytra (cythara), bębny (tympana), organy (organum), kymbalony (cymbala) (por. Zasady muzyki 19). W komentarzu do Psalmu 80 Kasjodor pisze o mistycznej mocy muzyki w nawiązaniu m.in. do zburzenia murów Jerycha dźwiękiem trąb (por. PL 70, 587; Kieling, Rola Pisma 191-92). Teologiczne znaczenie instrumentów, zwłaszcza cytry i harfy o dziesięciu strunach, Kalabryjczyk wyjaśnia również w Expositio in Psalterium, komentując Psalm 32. Jak już wspomniano wcześniej, harfa o dziesięciu strunach oznacza Dekalog, natomiast cytra wskazuje na ludzką pracę, która chociaż jest pełna napięć i trudów, to jednak przynosi owoce radości (por. PL 70, 226). Do teologicznego znaczenia cytry Kasjodor powraca w komentarzu do Psalmu 56 i ukazuje ten instrument w pasyjnej perspektywie zbawienia dokonanego przez Chrystusa na krzyżu. Cytra symbolizuje cierpiące ciało Jezusa, które podczas męki było napięte do granic wytrzymałości, ścięgna naprężone i kości policzone. Jednak dzięki swej cierpliwości ukrzyżowany Zbawiciel rozbrzmiewał duchową pieśnią cnót (por. PL 70, 404; Kobielus 233-41).

Założyciel Vivarium, wskazując na pochodzenie nazwy „Psałterz” od instrumentu muzycznego (psalterium), zaznacza: „Nie ma wątpliwości, że również Psałterz analogicznie do instrumentu muzycznego został nazwany, ponieważ w nim zawiera się bardzo słodki i wdzięczny śpiew zastępów anielskich" (Zasady muzyki 19). W tej niezwykłej metaforze Kasjodor nie zatrzymuje się tylko na 
analizie etymologicznej, ale snuje na tym tle refleksję teologiczną dotyczącą anielskiej natury śpiewu liturgicznego. Jak zauważa Lucjan Dyka, Kasjodor „Księgę Psalmów wyobraża sobie jako doskonały instrument muzyczny, na którym swoje słodkie wdzięczne śpiewy wykonują zastępy niebieskie. (...) Teksty Psalmów są natchnione i ich autorstwo jest caeleste (niebiańskie). (...) Ludzie wykonujący Psalmy upodabniają się do aniołów i przenoszą się w sferę nadprzyrodzoną" (Dyka 53). Myśl tę odnajdujemy we wprowadzeniu do Księgi Psalmów, gdzie założyciel Vivarium, mając w pamięci mnichów gromadzących się na wspólnej modlitwie, daje wyraz swemu przekonaniu o mistycznym charakterze śpiewu liturgicznego: „Psalmy uprzyjemniają nam czuwanie, gdy podczas śpiewu chórów wśród ciszy nocnej wzbija się głos ludzki z muzyką, która łącząc się ze słowami przedziwnie powiązanymi, zwraca ducha ku Temu, od którego wyszło Boskie Słowo dla zbawienia rodzaju ludzkiego. Śpiew ten, który raduje uszy i uszlachetnia ducha, brzmi jednozgodnie, i pozwala nam w chwaleniu Boga łączyć się z aniołami, choć ich samych zobaczyć nie możemy" (PL 70, 10).

Rozważając teologiczny wymiar muzyki, Kasjodor nawiązywał nie tylko do duchowego bogactwa psalmów, ale także do innych fragmentów Pisma Świętego. W rozdziale dziewiątym Institutiones musicae, zwrócił uwagę na powszechne w świecie antycznym przekonanie o uzdrawiającej i katarktycznej mocy muzyki, przynoszącej ulgę ludziom, którzy doświadczają melancholii, depresji i wewnętrznego niepokoju. Biblijnym tego odzwierciedleniem jest historia Saula i Dawida. Medytując nad nią Kasjodor pyta: „Cóż powiemy o Dawidzie, który uwolnił Saula od duchów nieczystych za pomocą uzdrawiającej umiejętności śpiewania i w ten niezwykły sposób przez dźwięk przyniósł królowi zdrowie, którego lekarze nie mogli osiągnąć mocą ziół leczniczych?" (Zasady muzyki 25). Odwołując się do tekstu biblijnego (1 Sm 16, 14-23), Kasjodor interpretuje go dość swobodnie. W Institutiones musicae nie tyle zajmuje się terapeutycznym wymiarem gry Dawida na instrumencie strunowym (najprawdopodobniej była to kitara), ile raczej skupia się na jego śpiewie. Natomiast w Epistola ad Boetium, odnosząc się do tej sceny biblijnej, zwraca uwagę również na instrumentalny wymiar muzyki, która nie tylko uzdrawia (tzw. effectus musicae), ale także spełnia rolę egzorcyzmu: „Lira dawidowa wypędziła diabła" (Pepulit Davidica lyra diabolum) (PL 69, 572; por. Dyka 132-35; Witkowska-Zaremba 44-45). Mocą muzyki pochodzącej z Bożego Ducha (por. 2 Sm 23, 2), Dawid mógł przezwyciężać działanie złej mocy, która sprowadzała na króla Saula ataki szału. Ta symbolika wskazuje nie tylko na terapeutyczny, ale także teologiczno-moralny wymiar wykonywanej przez 
Dawida muzyki, która miała na celu wyzwolenie i oczyszczenie od zła, czyli działanie katarktyczne o charakterze egzorcyzmu. Do zagadnienia uzdrawiającej mocy muzyki Kasjodor powracać będzie także w Expositio in Psalterium, komentując m.in. Psalmy 32 i 134 (Kieling, Rola Pisma 158). Również Ojcowie Kościoła i średniowieczni teologowie (m.in. św. Nicetas z Remezjany, św. Izydor z Sewilli, św. Beda Czcigodny, Honoriusz z Autun, Hugo od św. Wiktora) interpretowali stan Saula jako rodzaj opętania demonicznego, a lirę Dawida przyrównywali symbolicznie do krzyża Chrystusa, który przyniósł człowiekowi wyzwolenie z niewoli złego ducha (por. Howe 539-59).

\section{ZAKOŃCZENIE}

Analiza poglądów Kasjodora na temat muzyki pozwala stwierdzić, że stanowią one syntezę elementów pitagoreizmu i religii chrześcijańskiej. Jego zasługi w dziedzinie teorii muzyki porównać można do budowania mostu pomiędzy intelektualnym dziedzictwem greckiego antyku a „nową pieśnią” chrześcijaństwa. Założyciel Vivarium, kontynuując dziedzictwo myśli antycznej, jednocześnie uczy odczytywać je w duchu Chrystusowej Ewangelii. Przez to Kasjodora zaliczyć można do grona tych myślicieli wczesnochrześcijańskich, którzy położyli podwaliny cywilizacji łacińskiej. Feliks Koneczny, doceniając wielkie znaczenie Kasjodora dla kultury europejskiej, stwierdził: „Vivarium... działa dotychczas. (...) My wszyscy łacinnicy jesteśmy jego potomstwem" (Cywilizacja bizantyńska 163). Także Benedykt XVI zwraca uwagę na niezwykłą aktualność przesłania Kasjodora: „My również żyjemy bowiem w epoce spotkania kultur i zagrożenia przemocą, która burzy kultury, oraz stoimy w obliczu konieczności przekazania wielkich wartości nowym pokoleniom i wprowadzania ich na drogę pojednania i pokoju. Drogę tę znajdujemy, szukając Boga z ludzkim obliczem — Boga, który objawił się nam w Chrystusie” (Benedykt XVI 47).

BIBLIOGRAFIA

ŹRÓDŁA

Aurelius Cassiodorus. Epistola XL: Boethio patricio Theodericus rex. PL 69, 570-573.

Aurelius Cassiodorus. Expositio in Psalterium. PL 70, 9-1056.

Kasjodor (Flavius Magnus Aurelius Cassiodorus). Institutiones musicae. Zasady muzyki. Z języka tacińskiego przełożyl, wstępem i komentarzem opatrzyt oraz słownik sporządzil Lucjan Dyka. Wydawnictwo Uniwersytetu Rzeszowskiego, Instytut Teologiczno-Pastoralny im. św. Józefa Sebastiana Pelczara w Rzeszowie, 2015. Musica Antiqua et Medii Aevi 1. 


\section{LITERATURA PRZEDMIOTU}

Bäbler, Balbina. „Vivarium. Topographie, Religion, und Paideia”. Aiônos. Miscellanea di Studi Storici, nr 22, 2018-2019, ss. 107-132.

Benedykt XVI. „Boecjusz i Kasjodor”. L'Osservatore Romano, nr 4, 2008, ss. 45-47.

Bower, Calvin. „Cassiodorus”. The New Grove Dictionary of Music and Musicians, red. Stanley Sadie, t. 3, Oxford UP, 2001, ss. 244-245.

Copleston, Frederick. Historia filozofii, t. 2, Instytut Wydawniczy PAX, 2004.

Daniélou Jean, i Henri Irenée Marrou. Historia Kościoła, t. 1, Instytut Wydawniczy PAX, 1986.

Fubini, Enrico. Historia estetyki muzycznej. Musica Iagellonica, 1997.

Gondek, Maria Joanna. „Koncepcja edukacji Kasjodora i jej znaczenie dla kultury Zachodu”. Człowiek w kulturze, nr 16, 2004, ss. 125-144.

Howe, Blake. „Saul, David, and Music's Ideal Body”. The Oxford Handbook of Music and Disability Studies, red. Blake Howe i in., Oxford UP, 2016, ss. 539-559.

James, Jamie. Muzyka sfer. O muzyce, nauce i naturalnym porządku świata. Tłum. Mieczysław Godyń, Znak, 1996.

Jan Paweł II. Encyklika Fides et ratio. Libreria Editrice Vaticana, 1998.

Kieling, Michał. „Ars musica w grecko-rzymskiej kulturze antycznej oraz chrześcijaństwie pierwszych wieków". Dei enim sumus adiutores. Opuscula Adamo Przybecki septuagenario dedicata, red. Mieczysław Polak, Uniwersytet im. Adama Mickiewicza w Poznaniu, Wydział Teologiczny, 2019.

Kieling, Michał. Rola Pisma Świętego i artes liberales w ksztaltowaniu nauk teologicznych $i$ świeckich wedlug Kasjodora. Wydział Teologiczny Uniwersytetu Adama Mickiewicza, 2011.

Kobielus, Stanisław. Krzyż Chrystusa. Od znaku i figury do symbolu i metafory. Instytut Wydawniczy PAX, 2000

Koneczny, Feliks. Cywilizacja bizantyńska. Wydawnictwo Antyk Marcin Dybowski, 1973.

Koneczny, Feliks. Obronić cywilizację łacińską. Fundacja Rozwoju Kultury Polskiej, 2002.

Longosz, Stanisław. „Kasjodor”. Powszechna Encyklopedia Filozofii, red. Andrzej Maryniarczyk, t. 5, Polskie Towarzystwo Tomasza z Akwinu, 2004, ss. 529-534.

Longosz, Stanisław. „Patrystyczne traktaty o muzyce”. In persona Christi. Księga Pamiatkowa na 80-lecie ks. prof. Cz. Bartnika, t. 1, red. Krzysztof Góźdź, Wydawnictwo KUL, 2009, ss. 183-205.

Lohr, Mikołaj. „Kasjodora klasztor Vivarium”. Studia Warmińskie, nr 2, 1965, ss. 371-387.

Lohr, Mikołaj. „Zagadnienia muzyki w pismach Kasjodora i ich źródła”. Studia Warmińskie, nr 3, 1966, ss. 301-315.

Marsden, Richard. The Text of the Old Testament in Anglo-Saxon England. Cambridge UP, 1995.

Morawski, Jerzy. Teoria muzyki w średniowieczu. Wybrane zagadnienia. Akademia Teologii Katolickiej, 1979.

Pagano, Mario. Cassiodoro e la sua famiglia il Vivarium. Nuove ricerche storico-archeologiche. Belle Epoque Edizioni, 2020.

Szczeklik, Andrzej. Katharsis. O uzdrowicielskiej mocy natury i sztuki. Znak, 2003.

Tatarkiewicz, Władysław. Historia estetyki, t. 2, Wydawnictwo Naukowe PWN, 2009. 
Williams, David Russell, i Matthew Balensuela. Music Theory from Boethius to Zarlino: A Bibliography and Guide. Pendragon Press Hillsdale, 2007.

Witkowska-Zaremba, Elżbieta. „Cassiodorus Senator”. Encyklopedia Muzyczna PWM, red. Elżbieta Dziębowska, t. 2, Polskie Wydawnictwo Muzyczne, 1984, s. 44-45.

Zwolski, Edward. Kasjodor i Jordanes. Historia gocka czyli scytyjska Europa. Towarzystwo Naukowe KUL, 1984.

\section{TEOLOGICZNE ASPEKTY MUZYKI W UJĘCIU FLAWIUSZA AURELIUSZA KASJODORA}

\section{Streszczenie}

Niniejszy artykuł jest próbą przedstawienia głównych wątków teologii muzyki w ujęciu Kasjodora (ok. 485-580), którego życiowym posłannictwem było zachowanie grecko-rzymskich wartości kulturowych. Pracował nad syntezą kultury starożytnej z kulturą świata chrześcijańskiego. Przyczynił się do ocalenia spuścizny myśli antycznej w czasach zamętu i barbarzyństwa. Był wzorem spotkania kultur, dialogu, pojednania. Kasjodor założył Vivarium - wspólnotę monastyczną, w której praca intelektualna mnicha była uznawana za niezwykle cenną. Dla ludzi Kościoła, takich jak Kasjodor, wielką wartością sztuk wyzwolonych, w tym muzyki, była taka formacja intelektualna chrześcijanina, aby mógł on rozumieć Pismo Święte. Jego dzieła dotyczące muzyki są szczególnie cenne dla studiów nad początkami muzyki kościelnej. Bogaty dorobek naukowy Kasjodora w tej dziedzinie czyni go prekursorem teologicznej refleksji nad muzyką.

Słowa kluczowe: Kasjodor; teologia muzyki; muzyka wczesnochrześcijańska; Vivarium.

\section{THEOLOGICAL ASPECTS OF MUSIC AS SEEN BY FLAVIUS AURELIUS CASSIODORUS}

\section{S u m m a ry}

This article is an attempt to present the main themes of the theology of music from the point of view of Cassiodorus (c. 485-580). He spent his life trying to preserve Greco-Roman cultural traditions, and worked to harmonise the culture of the ancient with that of the Christian world. He helped to save ancient culture at a time of impending barbarism, and was a model of cultural encounter, dialogue and reconciliation. Cassiodorus founded Vivarium, a coenobitic community in which everything was organised in such a way that an individual monk's intellectual work was highly esteemed. For church men like Cassiodorus, the great value of the liberal arts, including music, inspired the intelligence needed by Christians to understand Scripture. His works on music are particularly valuable for the study of the early beginnings of church music. Cassiodorus's rich scientific achievements in this field make him a forerunner of theological reflection on music.

Keywords: Cassiodorus; theology of music; early Christian music; Vivarium. 